\title{
Conservation and sustainable use of medicinal plants: problems, progress, and prospects
}

Shi-Lin Chen ${ }^{1 *}$, Hua Yu ${ }^{2,3^{*}}$, Hong-Mei Luo ${ }^{2}$, Qiong Wu ${ }^{2,4}$, Chun-Fang Li ${ }^{2}$ and André Steinmetz ${ }^{5}$

\begin{abstract}
Medicinal plants are globally valuable sources of herbal products, and they are disappearing at a high speed. This article reviews global trends, developments and prospects for the strategies and methodologies concerning the conservation and sustainable use of medicinal plant resources to provide a reliable reference for the conservation and sustainable use of medicinal plants. We emphasized that both conservation strategies (e.g. in situ and ex situ conservation and cultivation practices) and resource management (e.g. good agricultural practices and sustainable use solutions) should be adequately taken into account for the sustainable use of medicinal plant resources. We recommend that biotechnical approaches (e.g. tissue culture, micropropagation, synthetic seed technology, and molecular marker-based approaches) should be applied to improve yield and modify the potency of medicinal plants.
\end{abstract}

\section{Background}

Medicinal plants are globally valuable sources of new drugs [1-4]. There are over 1300 medicinal plants used in Europe, of which $90 \%$ are harvested from wild resources; in the United States, about 118 of the top 150 prescription drugs are based on natural sources [5]. Furthermore, up to $80 \%$ of people in developing countries are totally dependent on herbal drugs for their primary healthcare, and over $25 \%$ of prescribed medicines in developed countries are derived from wild plant species [4]. With the increasing demand for herbal drugs, natural health products, and secondary metabolites of medicinal plants, the use of medicinal plants is growing rapidly throughout the world $[1,6]$.

A highly conservative estimate states that the current loss of plant species is between 100 and 1000 times higher than the expected natural extinction rate and that the Earth is losing at least one potential major drug every 2 years [7]. According to the International Union for Conservation of Nature and the World Wildlife Fund,

\footnotetext{
*Correspondence: slchen@icmm.ac.cn; yh_2003@126.com

${ }^{1}$ Institute of Chinese Materia Medica, China Academy of Chinese Medical Sciences, Beijing 100700, China

3 Shandong Center of Crop Germplasm Resources, Jinan 250100, China Full list of author information is available at the end of the article
}

there are between 50,000 and 80,000 flowering plant species used for medicinal purposes worldwide. Among these, about 15,000 species are threatened with extinction from overharvesting and habitat destruction [8] and $20 \%$ of their wild resources have already been nearly exhausted with the increasing human population and plant consumption [9]. Although this threat has been known for decades, the accelerated loss of species and habitat destruction worldwide has increased the risk of extinction of medicinal plants, especially in China $[1,10]$, India [10, 11], Kenya [11], Nepal [11], Tanzania [12] and Uganda [12].

The conservation and sustainable use of medicinal plants have been studied extensively $[13,14]$. Various sets of recommendations have been compiled regarding their conservation, including the establishment of systems for species inventorying and status monitoring, and the need for coordinated conservation practices based on both in situ and ex situ strategies [4]. For medicinal plants with increasingly limited supplies, sustainable use of wild resources can be an effective conservation alternative. In China and South Africa, the situation is particularly critical because of the high demands of large populations.

This article reviews global trends, developments and prospects of the strategies and methodologies concerning 
the conservation and sustainable use of medicinal plant resources.

\section{Review}

\section{Literature search}

We conducted systematic literature searches in the ISI Web of Science, PubMed and CNKI databases using search terms (e.g. "medicinal plant", "herbal drug", "herbal medicine", "aromatic plant", and "Chinese medicine") and keyword combinations (e.g. "in situ conservation", "ex situ conservation", "sustainable use", and "cultivation practice") to retrieve the abstracts of relevant articles (Fig. 1). The literature search spanned the period from January 2000 to December 2014, and the languages were limited to English and Chinese. We carefully reviewed all retrieved abstracts to find articles that were suitable according to the inclusion criteria (Table 1). For literature focusing on the conservation and/or sustainable use of medicinal plants, we retrieved full articles from fulltext databases (ScienceDirect, Wiley, Biomed, Springer, Medline, Scopus, Elsevier, Highwire, Mcgill, Cogprints, Emedicine, Nature and Science online). From the initial search, a total of 673 abstracts were collected, including

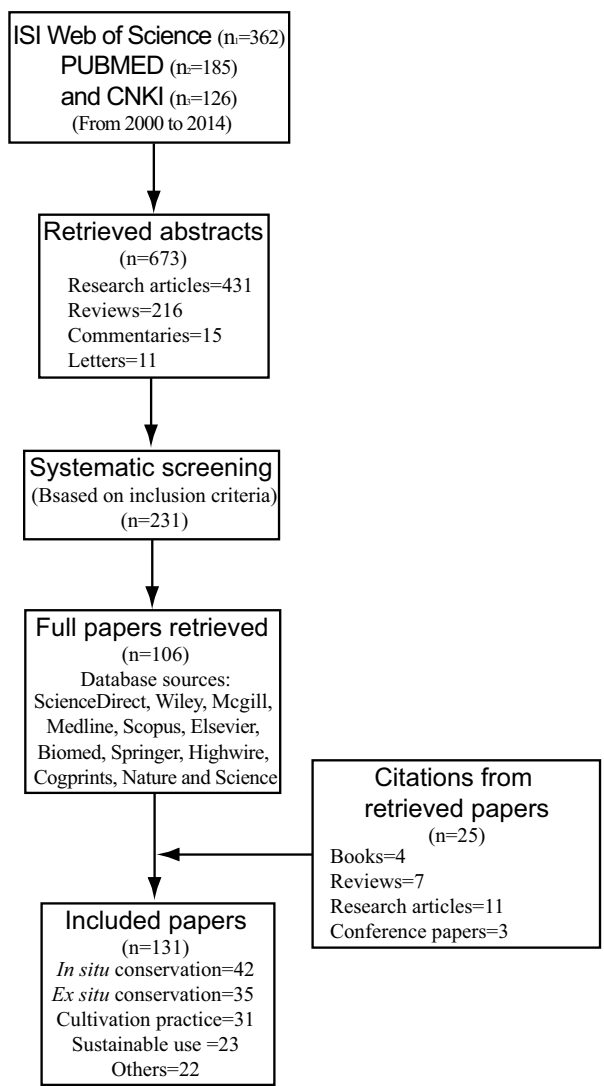

Fig. 1 Diagram for literature selection research articles, reviews, commentaries and letters. After systematic screening, 231 met the inclusion criteria. From these, full copies of 106 articles were retrieved for further evaluation. In addition, we retrieved 25 nonindexed but relevant citations from the reference lists of retrieved articles to supplement the above searches and provide a complete literature retrieval.

\section{Diversity of medicinal plants used worldwide}

More than one-tenth of plant species are used in drugs and health products, with more than 50,000 species being used. However, the distribution of medicinal plants is not uniform across the world $[15,16]$. For example, China and India have the highest numbers of medicinal plants used, with 11,146 and 7500 species, respectively, followed by Colombia, South Africa, the United States, and another 16 countries with percentages of medicinal plants ranging from $7 \%$ in Malaysia to $44 \%$ in India versus their total numbers of plant species [16-19] (Fig. 2). Certain plant families not only have higher numbers of medicinal plants, but also have higher proportions of threatened species than others [15]. Only a portion of medicinal plants that suffer from genetic erosion and resource destruction have been listed as threatened [20, 21].

\section{Factors related to species rarity of medicinal plants}

Species rarity is used to assess the extinction risk of medicinal plants, and to identify those species most at risk of extinction, prior to commencement of conservation efforts [22]. It is necessary to determine how rare each species is and in which ways rare species differ from one another. Not all medicinal plants are affected in the same way by harvesting pressures [23, 24]. Overexploitation, indiscriminate collection, uncontrolled deforestation, and habitat destruction all affect species rarity, but are insufficient to explain individual species susceptibility or resilience to harvest pressure. Multiple biological characters correlate with extinction risk, such as habitat specificity, distribution range, population size, species diversity, growth rate, and reproductive system (Table 2; Fig. 3).

\section{Conservation strategies}

Medicinal plant resources are being harvested in increasing volumes, largely from wild populations. Indeed, demand for wild resources has increased by $8-15 \%$ per year in Europe, North America, and Asia in recent decades $[8,9]$. There is a threshold below which species reproductive capacity becomes irreversibly reduced [25, 26]. Various sets of recommendations relating to the conservation of medicinal plants have been developed, such as providing both in situ and ex situ conservation 
Table 1 The inclusion and exclusion criteria for study selection

\begin{tabular}{ll}
\hline Subjects & Criteria description \\
\hline Inclusion criteria & The subject is about medicinal plants \\
& The purpose is to conserve or sustainably use \\
It has a detailed description of the strategy of conservation, sustainable use or resource management \\
Consistent to the three items simultaneously \\
The subject is not related to medicinal plants (e.g. animals or mineral substances) \\
The purpose is not for conservation or sustainable use of medicinal plants (e.g. herb extraction, drug discovery, chemical constituent \\
or pharmacological property) \\
It has no description of the strategy of conservation, sustainable use or resource management of medicinal plants
\end{tabular}

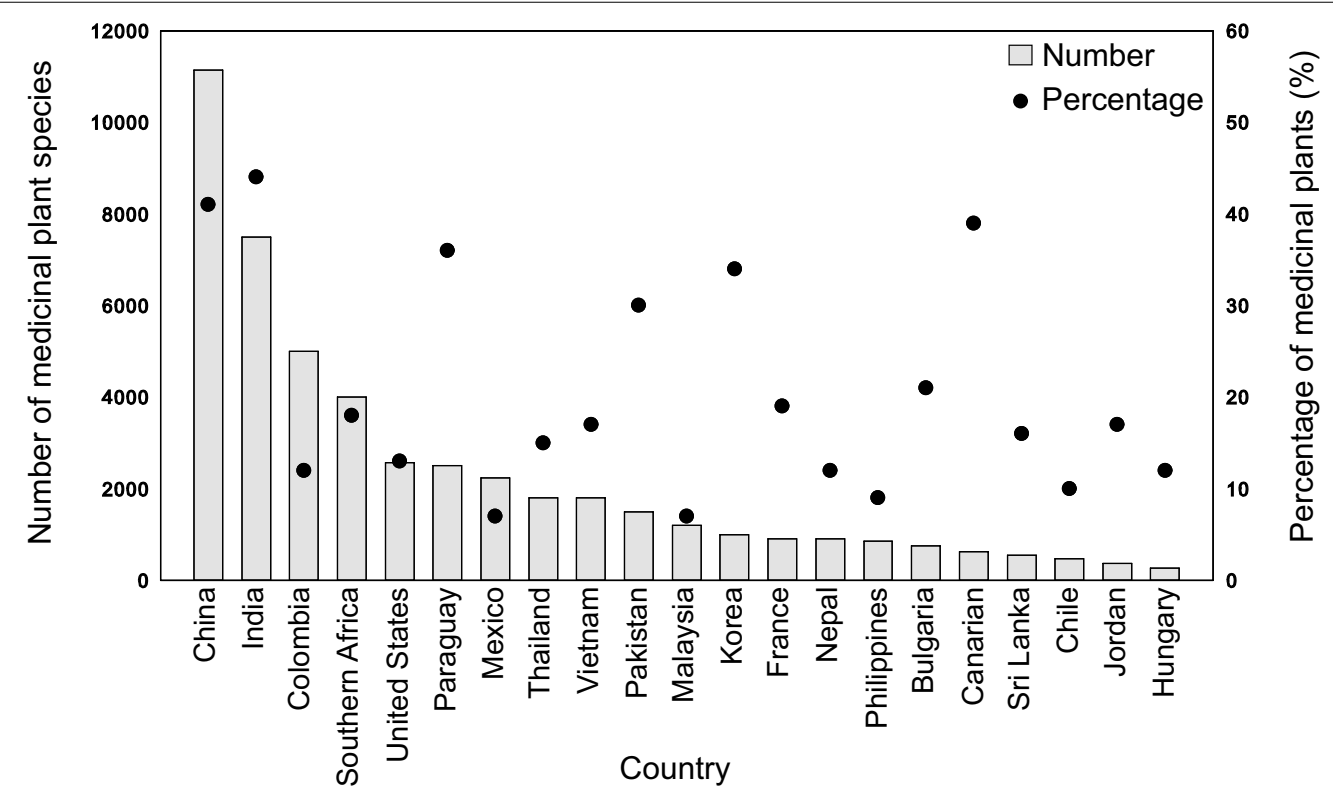

Fig. 2 Number and percentage of medicinal plant species in different countries. The light bars indicate the number of medicinal plant species, and the dark dots indicate the percentage of medicinal plants compared with the total number of plant species. Data sources from Rafieian-Kopaei [16], Hamilton [17], Marcy et al. [18], and Srujana et al. [19]

(Table 2) [15, 27]. Natural reserves and wild nurseries are typical examples to retain the medical efficacy of plants in their natural habitats, while botanic gardens and seed banks are important paradigms for ex situ conservation and future replanting [28, 29] (Fig. 4). The geographic distribution and biological characteristics of medicinal plants must be known to guide conservation activities, e.g. to assess whether species conservation should take place in nature or in a nursery.

\section{In situ conservation}

Most medicinal plants are endemic species, and their medicinal properties are mainly because of the presence of secondary metabolites that respond to stimuli in natural environments, and that may not be expressed under culture conditions [22, 29]. In situ conservation of whole communities allows us to protect indigenous plants and maintain natural communities, along with their intricate network of relationships [30]. Additionally, in situ conservation increases the amount of diversity that can be conserved [31], and strengthens the link between resource conservation and sustainable use [32]. In situ conservation efforts worldwide have focused on establishing protected areas and taking an approach that is ecosystem-oriented, rather than species-oriented [33]. Successful in situ conservation depends on rules, regulations, and potential compliance of medicinal plants within growth habitats [25, 34].

Natural reserves The degradation and destruction of habitats is a major cause of the loss of medicinal plant resources [35]. Natural reserves are protected areas of 


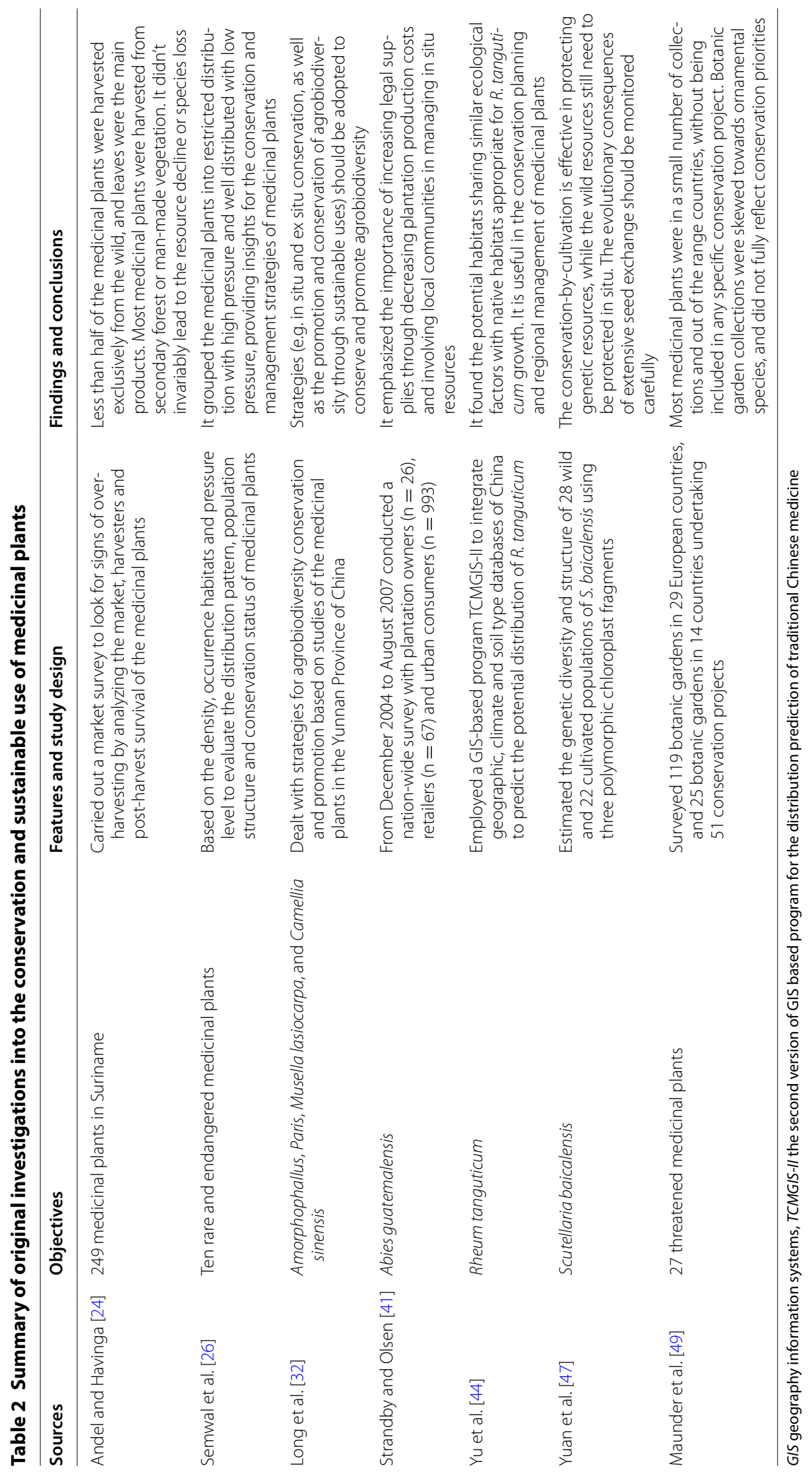




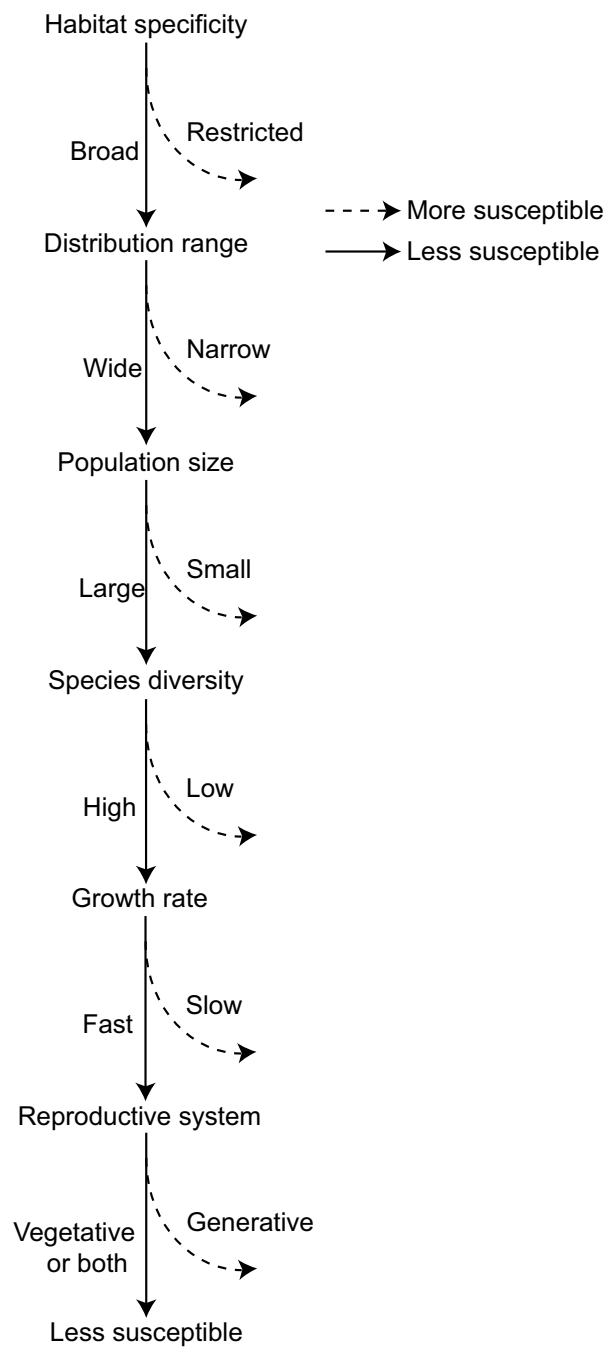

Fig. 3 Factors contributing to the susceptibility or resilience of medicinal plants in response to collection pressure. Factors include distribution range, habitat specificity, population size, species diversity, growth rate, and reproductive system. The dark line indicates less susceptible characteristics of medicinal plants, while the dashed line indicates more susceptible characteristics contributing to the rarity of medicinal plants

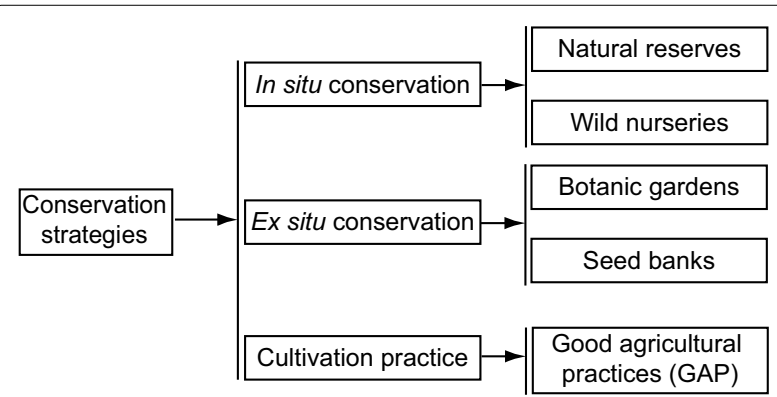

Fig. 4 Diagram of methodological systems involved in the conservation of medicinal plants important wild resources created to preserve and restore biodiversity [36, 37]. Around the world, more than 12,700 protected areas have been established, accounting for 13.2 million $\mathrm{km}^{2}$, or $8.81 \%$ of the Earth's land surface [38]. Conserving medicinal plants by protecting key natural habitats requires assessing the contributions and ecosystem functions of individual habitats [39].

Wild nurseries It is impossible to designate every natural wild plant habitat as a protected area, owing to cost considerations and competing land uses [25, 40]. A wild nursery is established for species-oriented cultivating and domesticating of endangered medicinal plants in a protected area, natural habitat, or a place that is only a short distance from where the plants naturally grow $[4,20,41]$. Although the populations of many wild species are under heavy pressure because of overexploitation, habitat degradation and invasive species, wild nurseries can provide an effective approach for in situ conservation of medicinal plants that are endemic, endangered, and in-demand [27, 42].

\section{Ex situ conservation}

Ex situ conservation is not always sharply separated from in situ conservation, but it is an effective complement to it, especially for those overexploited and endangered medicinal plants with slow growth, low abundance, and high susceptibility to replanting diseases [4, 43, 44]. Ex situ conservation aims to cultivate and naturalize threatened species to ensure their continued survival and sometimes to produce large quantities of planting material used in the creation of drugs, and it is often an immediate action taken to sustain medicinal plant resources $[45,46]$. Many species of previously wild medicinal plants can not only retain high potency when grown in gardens far away from the habitats where they naturally occur, but can have their reproductive materials selected and stored in seed banks for future replanting [4].

Botanic gardens Botanic gardens play an important role in ex situ conservation [43], and they can maintain the ecosystems to enhance the survival of rare and endangered plant species [38]. Although living collections generally consist of only a few individuals of each species and so are of limited use in terms of genetic conservation [47], botanic gardens have multiple unique features. They involve a wide variety of plant species grown together under common conditions, and often contain taxonomically and ecologically diverse flora [48]. Botanic gardens can play a further role in medicinal plant conservation through the development of propagation and cultivation protocols, as well as undertaking programs of domestication and variety breeding [49]. 
Seed banks Seed banks offer a better way of storing the genetic diversity of many medicinal plants ex situ than through botanic gardens, and are recommended to help preserve the biological and genetic diversity of wild plant species $[50,51]$. The most noteworthy seed bank is the Millennium Seed Bank Project at the Royal Botanic Gardens in Britain [51]. Seed banks allow relatively rapid access to plant samples for the evaluation of their properties, providing helpful information for conserving the remaining natural populations $[50,51]$. The challenging tasks of seed banking are how to reintroduce the plant species back into the wild and how to actively assist in the restoration of wild populations [50].

\section{Cultivation practice}

Although wild-harvested resources of medicinal plants are widely considered more efficacious than those that are cultivated, domestic cultivation is a widely used and generally accepted practice $[30,52,53]$. Cultivation provides the opportunity to use new techniques to solve problems encountered in the production of medicinal plants, such as toxic components, pesticide contamination, low contents of active ingredients, and the misidentification of botanical origin [54]. Cultivation under controlled growth conditions can improve the yields of active compounds, which are almost invariably secondary metabolites, and ensures production stability (Table 3). Cultivation practices are designed to provide optimal levels of water, nutrients, optional additives, and environmental factors including temperature, light and humidity to obtain improved yields of target products $[27,55]$. Moreover, increased cultivation contributes to decreases in the harvest volume of medicinal plants, benefits the recovery of their wild resources, and decreases their prices to a more reasonable range $[4,13,20]$ (Fig. 5).

\section{Good agricultural practices (GAP)}

Good agricultural practices (GAP) for medicinal plants have been formulated to regulate production, ensure quality, and facilitate the standardization of herbal drugs [56]. A GAP approach ensures high quality, safe and pollution-free herbal drugs (or crude drugs) by applying available knowledge to address various problems [57]. GAP include comprehensive items, such as the ecological environment of production sites, germplasm, cultivation, collection, and quality aspects of pesticide detection, macroscopic or microscopic authentication, chemical identification of bioactive compounds, and inspection of metal elements [58]. Many countries actively promote the implementation of GAP. For example, Chinese authorities have promoted GAP for the growth of commonly used herbal drugs in regions where those medicinal plants are traditionally cultivated [27,33].

Organic farming has received increasing attention for its ability to create integrated, humane, and environmentally and economically sustainable production systems

Table 3 The advantages and disadvantages of wild resource versus cultivated medicinal plant species

\begin{tabular}{|c|c|c|}
\hline Characteristics & Wild resource & Cultivated species \\
\hline \multirow[t]{4}{*}{ Advantages } & It is open access resource without investment & It relieves harvesting pressure on rare and threatened species \\
\hline & It is natural resource and free from pesticides & It can keep genotypes being standardized or improved \\
\hline & Wild resource is supposed to be more efficacious & It guarantees continuing supply of raw medicinal materials \\
\hline & & Production volume and price can be stable for longer periods \\
\hline \multirow[t]{5}{*}{ Disadvantages } & $\begin{array}{l}\text { Wild resource is becoming scarce and threatened by over- } \\
\text { harvesting }\end{array}$ & It needs substantial investment before and during production \\
\hline & There exists a risk of adulterations and resource exhaustion & It narrows genetic diversity in gene pool of wild populations \\
\hline & $\begin{array}{l}\text { Uncontrolled harvesting leads to the extinction of ecotype and } \\
\text { species }\end{array}$ & Reintroduced plants can cause genetic pollution of wild resource \\
\hline & There is a lack of resource inventories and related management & Cultivated species may have negative impacts on ecosystems \\
\hline & & $\begin{array}{l}\text { There is a lack of successful cultivation techniques for some spe- } \\
\text { cies }\end{array}$ \\
\hline
\end{tabular}

Information from Hamilton [4], Schippmann et al. [20], Liu et al. [27], and Raina et al. [54] 


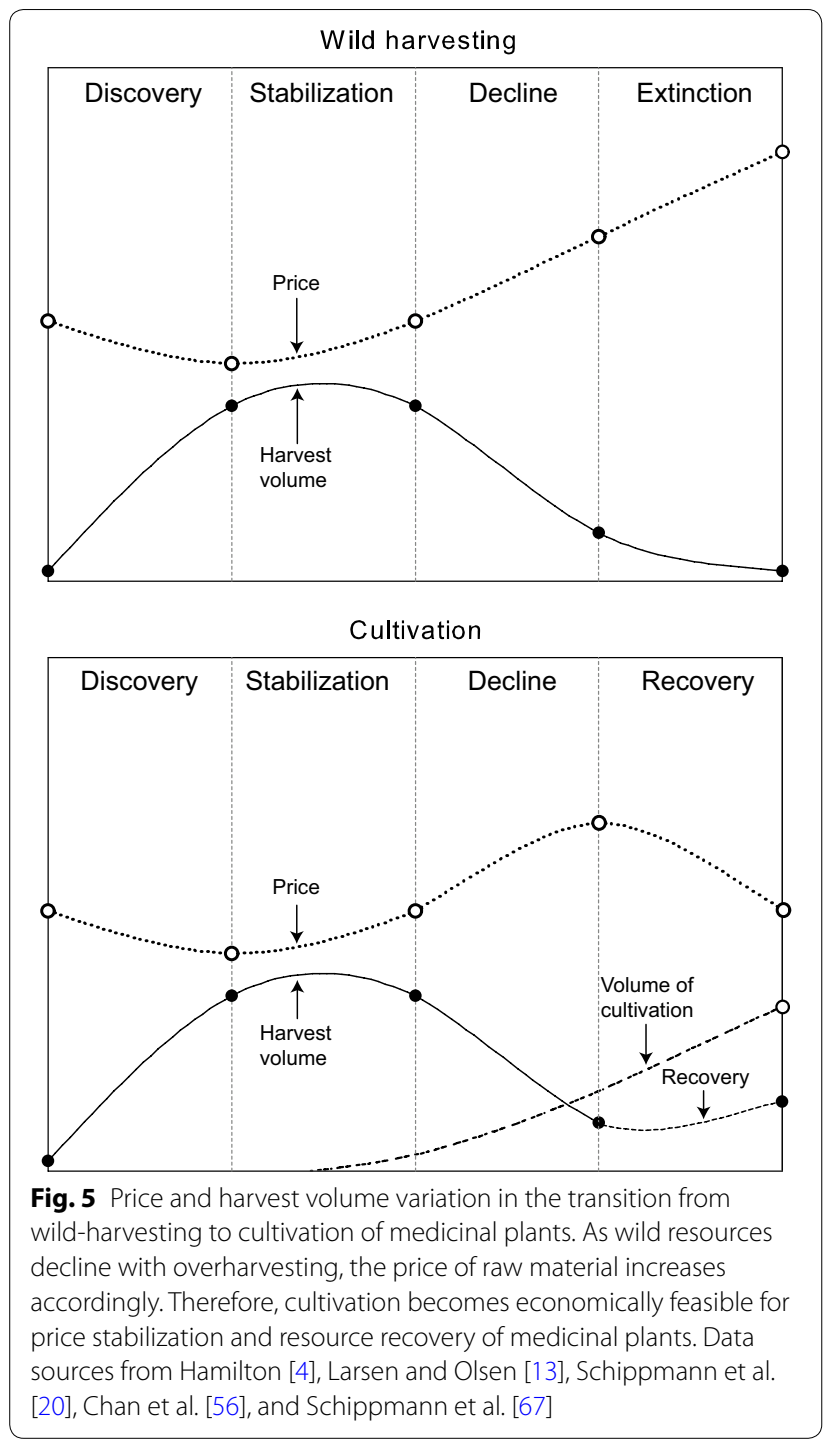

for medicinal plants, $[59,60]$. The aims of organic farming of medicinal plants include producing material with better quality and high productivity, and ensuring the conservation and sustainable utilization of those plants (Table 4). The defining characteristic of organic farming is the non-use of synthetic fertilizers, pesticides and herbicides, which are not allowed according to many current organic certification standards in Europe and North America [59]. Organic farming is benign to the environment, and relies upon farm-derived renewable resources to maintain biological processes of medicinal plants and ecological balance of habitates $[56,59]$.
The use of organic fertilizers continuously supplies soil nutrients and improves soil stability, significantly affecting the growth of medicinal plants and the biosynthesis of essential substances. For example, when organic fertilizers were applied, the biomass yield of Chrysanthemum balsamita was increased and its essential oil content was high relative to those free from organic fertilizers [61]. Organic farming of medicinal plants is becoming increasingly important in the long-term development and sustainability of medicinal plants [60].

\section{Sustainable use}

For medicinal plants with limited abundance and slow growth, destructive harvesting generally results in resource exhaustion and even species extinction [13, 62]. Therefore, the sustainable use of medicinal plants should be considered, and good harvesting practices must be formulated. Root and whole-plant harvesting is more destructive to medicinal plants (e.g. herbs, shrubs and trees) than collecting their leaves and flowers or buds (Table 5). For herbal drugs made of whole plants or roots, using their leaves as a remedy can be a benign alternative. For example, Wang et al. [63] discovered that extracts from ginseng leaf-stems and roots have similar pharmacological activities, but ginseng leaf-stem has the advantage of being a more sustainable resource.

\section{Prospects}

The development of genetic engineering has led to the feasibility of large-scale biosynthesis of natural products, and advancements in tissue culture and fermentation of medicinal plants have opened new avenues for the largescale and highly efficient production of desirable bioactive compounds. Tissue culture (including plant cell and transgenic hairy root culture) is a promising alternative for the production of rare and high-value secondary metabolites of medical importance [64]. Micropropagation via tissue encapsulation of propagules can not only facilitate storage and transportation, but also promotes higher regeneration rates [62]. When the amounts of normal seeds are insufficient for propagation, synthetic seed technology, defined as artificially encapsulated somatic embryos (or other tissues) could be used for cultivate in vitro or ex vitro, is a feasible alternative $[65,66]$. Furthermore, breeding improvements can be carried out using molecular marker-based approaches applied at the genetic level, and the time required for breeding may be significantly shortened $[62,64,65]$. 
Table 4 The characteristics and advantages of organic farming of medicinal plants

\begin{tabular}{|c|c|}
\hline Subjects & Characteristics and advantages of organic farming \\
\hline \multirow[t]{5}{*}{ Medicinal plants } & To produce material in optimal quality and sufficient quantity \\
\hline & To increase growth rate and biomass yield of medicinal plants \\
\hline & To enhance the biosynthesis of efficacious substances \\
\hline & To maintain the genetic diversity of medicinal plants \\
\hline & To protect medicinal plants against pests and disease \\
\hline \multirow[t]{7}{*}{ Environmental effects } & To prohibit the use of synthetic pesticides and fertilizers \\
\hline & To promote sustainable use and proper care of production systems \\
\hline & To enhance plant diversity and biotype conservation \\
\hline & To protect wildlife habitats (e.g. micro-organisms, soil fora and fauna) \\
\hline & To enhance soil rich in macro and microelements \\
\hline & To conserve soil properties, fertility, productivity and system stability \\
\hline & To use organic fertilizers and renewable resources to minimize all forms of pollution \\
\hline \multirow[t]{4}{*}{ Economic prospects } & To increase market opportunity \\
\hline & To maintain high market price \\
\hline & To achieve optimal quality and economic returns \\
\hline & To secure economic growth and social stability \\
\hline
\end{tabular}

Information from Rigby and Cáceres [59], Macilwain [60] and Suresh [61]

Table 5 Susceptibility of species to overharvesting regarding life forms and plant parts used

\begin{tabular}{|c|c|c|c|c|c|c|c|}
\hline Life form & $\begin{array}{l}\text { Percent } \\
(\%)\end{array}$ & Leave & Flower/bud & Fruit/seed & Bark & Root & Whole plant \\
\hline Herb & 52 & Medium & Medium & High & None & High & High \\
\hline Shrub & 16 & Low & Low & Low & High & High & High \\
\hline Tree & 22 & Low & Low & Low & High & High & High \\
\hline
\end{tabular}

Information from Schippmann et al. [67] and Teklehaymanot and Giday [68]

\section{Conclusion}

Despite the existence of various sets of recommendations for the conservation and sustainable use of medicinal plants, only a small portion of these have achieved adequate protection of medicinal plant resources through conventional conservation in natural reserves or botanic gardens.

\section{Abbreviations}

GAP: good agricultural practices.

\section{Authors' contributions}

SC and HY conceived and designed the study. SC, HY, HL and QW carried out the article searches. HY, QW and $\mathrm{CL}$ performed data analysis. SC, HY, HL and QW wrote the manuscript. CL and AS revised the manuscript. All authors read and approved the final manuscript.

\section{Author details}

${ }^{1}$ Institute of Chinese Materia Medica, China Academy of Chinese Medical Sciences, Beijing 100700, China. ${ }^{2}$ Institute of Medicinal Plant Development, Chinese Academy of Medical Sciences, Beijing 100193, China. ${ }^{3}$ Shandong Center of Crop Germplasm Resources, Jinan 250100, China. ${ }^{4}$ School of Pharmacy, Guilin Medical University, Guilin 541004, China. ${ }^{5}$ Plant Molecular Biology Laboratory, Centre de Recherche Public-Sante', 1526 Luxembourg, Luxembourg.

\section{Acknowledgements}

This study was supported by the National Natural Science Foundation of China (30900113) and the Natural Science Foundation of Shandong Province (ZR2013CQ038). All authors thank Dr. Xi-Wen Li, Liang Dong and Christine Leon for their helps on group discussion and manuscript polishing.

\section{Competing interests}

The authors declare that they have no competing interests.

Received: 20 April 2015 Accepted: 15 July 2016

Published online: 30 July 2016

\section{References}

1. Nalawade SM, Sagare AP, Lee CY, Kao CL, Tsay HS. Studies on tissue culture of Chinese medicinal plant resources in Taiwan and their sustainable utilization. Bot Bull Acad Sin. 2003;44:79-98.

2. Chen SL, Yao H, Han JP, Liu C, Song JY, Shi LC, Zhu YJ, Ma XY, Gao T, Pang XH, Luo K, Li Y, Li XW, Jia XC, Lin YL, Leon C. Validation of the ITS2 region as a novel DNA barcode for identifying medicinal plant species. PLOS ONE. 2010;5:e8613.

3. Chacko SM, Thambi PT, Kuttan R, Nishigaki I. Beneficial effects of green tea: a literature review. Chin Med. 2010;5:13.

4. Hamilton AC. Medicinal plants, conservation and livelihoods. Biodivers Conserv. 2004;13:1477-517.

5. Balunas MJ, Kinghorn AD. Drug discovery from medicinal plants. Life Sci. 2005;78:431-41. 
6. Cole IB, Saxena PK, Murch SJ. Medicinal biotechnology in the genus scutellaria. In Vitro Cell Dev Plant. 2007;43:318-27.

7. Pimm S, Russell G, Gittleman J, Brooks T. The future of biodiversity. Science. 1995;269:347.

8. Bentley R, editor. Medicinal plants. London: Domville-Fife Press; 2010. p. 23-46.

9. Ross IA, editor. Medicinal plants of the world (volume 3): chemical constituents, traditional and modern medicinal uses. New Jersey: Humana Press Inc; 2005. p. 110-32.

10. Heywood VH, Iriondo JM. Plant conservation: old problems, new perspectives. Biol Conserv. 2003:113:321-35.

11. Hamilton AC. Medicinal plants in conservation and development: case studies and lessons learned. In: Kala CP, editor. Medicinal plants in conservation and development. Salisbury: Plantlife International Publisher; 2008. p. 1-43.

12. Zerabruk S, Yirga G. Traditional knowledge of medicinal plants in Gindeberet district, Western Ethiopia. S Afr J Bot. 2012;78:165-9.

13. Larsen $\mathrm{HO}$, Olsen CS. Unsustainable collection and unfair trade? uncovering and assessing assumptions regarding Central Himalayan medicinal plant conservation. Biodivers Conserv. 2007;16:1679-97.

14. Uprety Y, Asselin H, Dhakal A, Julien N. Traditional use of medicinal plants in the boreal forest of Canada: review and perspectives. J Ethnobiol Ethnomed. 2012;8:1-14.

15. Huang H. Plant diversity and conservation in China: planning a strategic bioresource for a sustainable future. Bot J Linn Soc. 2011;166:282-300.

16. Rafieian-Kopaei M. Medicinal plants and the human needs. J Herb Med Pharm. 2013;1:1-2.

17. Hamilton A. Medicinal plant and conservation: issues and approaches. UK:WWF; 2003

18. Marcy J, Balunasa A, Kinghornb D. Drug discovery from medicinal plants Life Sci. 2005;78:431-41.

19. Srujana ST, Babu KR, Rao BSS. Phytochemical investigation and biological activity of leaves extract of plant Boswellia serrata. Pharm Innov. 2012;1:22-46.

20. Schippmann U, Leaman DJ, Cunningham AB, Walter S. Impact of cultivation and collection on the conservation of medicinal plants: global trends and issues. III WOCMAP congress on medicinal and aromatic plants: conservation, cultivation and sustainable use of medicinal and aromatic plants; 2005. Chiang Mai.

21. Deeb T, Knio K, Shinwari ZK, Kreydiyyeh S, Baydoun E. Survey of medicinal plants currently used by herbalists in Lebanon. Pak J Bot. 2013;45:543-55.

22. Figueiredo MSL, Grelle CEV. Predicting global abundance of a threatened species from its occurrence: implications for conservation planning. Divers Distrib. 2009:15:117-21.

23. Wagh WV, Jain AK. Status of threatened medicinal plants of Jhabua district, Madhya Pradesh, India. Ann Plant Sci. 2013:2:395-400.

24. Andel TV, Havinga R. Sustainability aspects of commercial medicinal plant harvesting in Suriname. Forest Ecol Manag. 2008;256:1540-5.

25. Soule ME, Estes JA, Miller B, Honnold DL. Strongly interacting species: conservation policy, management, and ethics. Bioscience. 2005;55:168-76.

26. Semwal DP, Saradhi PP, Nautiyal BP, Bhatt AB. Current status, distribution and conservation of rare and endangered medicinal plants of Kedarnath Wildlife Sanctuary, Central Himalayas, India. Curr Sci India. 2007:92:1733-8.

27. Liu C, Yu H, Chen SL. Framework for sustainable use of medicinal plants in China. Zhi Wu Fen Lei Yu Zi Yuan Xue Bao. 2011:33:65-8.

28. Sheikh K, Ahmad T, Khan MA. Use, exploitation and prospects for conservation: people and plant biodiversity of Naltar Valley, northwestern Karakorums, Pakistan. Biodivers Conserv. 2002;11:715-42.

29. Coley PD, Heller MV, Aizprua R, Arauz B, Flores N, Correa M, Gupta M, Solis PN, Ortega-Barría E, Romero LI, Gómez B, Ramos M, Cubilla-Rios L, Capson TL, Kursar TA. Using ecological criteria to design plant collection strategies for drug discovery. Front Ecol Environ. 2003;1:421-8.

30. Gepts P. Plant genetic resources conservation and utilization: the accomplishments and future of a societal insurance policy. Crop Sci. 2006;46:2278-92

31. Forest F, Grenyer R, Rouget M, Davies TJ, Cowling RM, Faith DP, Balmford A, Manning JC, Proche S, Bank M, Reeves G, Terry AJ, Savolainen V.
Preserving the evolutionary potential of floras in biodiversity hotspots. Nature. 2007;445:757-60.

32. Long CL, Li H, Ouyang ZQ, Yang XY, Li Q, Trangmar B. Strategies for agrobiodiversity conservation and promotion: a case from Yunnan, China. Biodivers Conserv. 2003:12:1145-56.

33. Ma J, Rong K, Cheng K. Research and practice on biodiversity in situ conservation in China: progress and prospect. Sheng Wu Duo Yang Xing. 2012;20:551-8

34. Volis S, Blecher M. Quasi in situ: a bridge between ex situ and in situ conservation of plants. Biodivers Conserv. 2010;19:2441-54.

35. Camm J, Norman S, Polasky S, Solow A. Nature reserve site selection to maximize expected species covered. Oper Res. 2002;50:946-55.

36. Rodriguez JP, Brotons L, Bustamante J, Seoane J. The application of predictive modelling of species distribution to biodiversity conservation. Divers Distrib. 2007;13:243-51.

37. Chiarucci A, Maccherini S, De Dominicis V. Evaluation and monitoring of the flora in a nature reserve by estimation methods. Biol Conserv. 2001:101:305-14.

38. Huang H, Han X, Kang L, Raven P, Jackson PW, Chen Y. Conserving native plants in China. Science. 2002;297:935.

39. Liu J, Linderman M, Ouyang Z, An L, Yang J, Zhang H. Ecological degradation in protected areas: the case of Wolong Nature Reserve for giant pandas. Science. 2001;292:98-101.

40. Kramer AT, Havens K. Plant conservation genetics in a changing world. Trends Plant Sci. 2009;14:599-607.

41. Strandby U, Olsen CS. The importance of understanding trade when designing effective conservation policy: the case of the vulnerable Abies guatemalensis Rehder. Biol Conserv. 2008;141:2959-68.

42. Li XW, Chen SL. Conspectus of ecophysiological study on medicinal plant in wild nursery. Zhong Guo Zhong Yao Za Zhi. 2007;32:1388-92.

43. Havens K, Vitt P, Maunder M, Guerrant EO, Dixon K. Ex situ plant conservation and beyond. Bioscience. 2006;56:525-31.

44. Yu H, Xie CX, Song JY, Zhou YQ, Chen SL. TCMGIS-II based prediction of medicinal plant distribution for conservation planning: a case study of Rheum tanguticum. Chin Med. 2010;5:31.

45. Swarts ND, Dixon KW. Terrestrial orchid conservation in the age of extinction. Ann Bot. 2009;104:543-56.

46. Pulliam HR. On the relationship between niche and distribution. Ecol Lett 2000;3:349-61.

47. Yuan QJ, Zhang ZY, Hu JA, Guo LP, Shao AJ, Huang LQ. Impacts of recent cultivation on genetic diversity pattern of a medicinal plant, Scutellaria baicalensis (Lamiaceae). BMC Genet. 2010;11:52-9.

48. Primack RB, Miller-Rushing AJ. The role of botanical gardens in climate change research. New Phytol. 2009;182:303-13.

49. Maunder M, Higgens S, Culham A. The effectiveness of botanic garden collections in supporting plant conservation: a European case study. Biodivers Conserv. 2001;10:383-401.

50. Li DZ, Pritchard HW. The science and economics of ex situ plant conservation. Trends Plant Sci. 2009;14:614-21.

51. Schoen DJ, Brown AHD. The conservation of wild plant species in seed banks. Bioscience. 2001:51:960-6.

52. Joshi BC, Joshi RK. The role of medicinal plants in livelihood improvement in Uttarakhand. Int J Herb Med. 2014:1:55-8.

53. Leung KW, Wong AS. Pharmacology of ginsenosides: a literature review. Chin Med. 2010:5:20

54. Raina R, Chand R, Sharma YP. Conservation strategies of some important medicinal plants. Int J Med Aromat Plant. 2011:1:342-7.

55. Wong KL, Wong RN, Zhang L, Liu WK, Ng TB, Shaw PC, Kwok PCL, Lai YM, Zhang ZJ, Zhang YB, Tong Y, Cheung H, Lu J, Wing SC. Bioactive proteins and peptides isolated from Chinese medicines with pharmaceutical potential. Chin Med. 2014;9:19.

56. Chan K, Shaw D, Simmonds MS, Leon CJ, Xu Q, Lu A, Sutherland I, Ignatova S, Zhu YP, Verpoorte R, Williamson EM, Duezk P. Good practice in reviewing and publishing studies on herbal medicine, with special emphasis on traditional Chinese medicine and Chinese materia medica. J Ethnopharmacol. 2012;140:469-75.

57. Muchugi A, Muluvi GM, Kindt R, Kadu CAC, Simons AJ, Jamnadass RH. Genetic structuring of important medicinal species of genus Warburgia as revealed by AFLP analysis. Tree Genet Genome. 2008;4:787-95. 
58. Makunga NP, Philander LE, Smith M. Current perspectives on an emerging formal natural products sector in South Africa. J Ethnopharmacol. 2008:119:365-75.

59. Rigby D, Cáceres D. Organic farming and the sustainability of agricultural systems. Agr Syst. 2001;68:21-40.

60. Macilwain C. Organic: is it the future of farming? Nature. 2004;428:792-3.

61. Suresh B. Organic farming: status, issues and prospects - a review. Agr Econ Res Rev. 2010;23:343-58.

62. Baker DD, Chu M, Oza U, Rajgarhia V. The value of natural products to future pharmaceutical discovery. Nat Prod Rep. 2007;24:1225-44.

63. Wang HW, Peng DC, Xie JT. Ginseng leaf-stem: bioactive constituents and pharmacological functions. Chin Med. 2009;4:20.

64. Rao SR, Ravishankar GA. Plant cell cultures: chemical factories of secondary metabolites. Biotechnol Adv. 2002;20:101-53.
65. Lata H, Chandra S, Khan IA, Elsohly MA. Propagation of Cannabis sativa L using synthetic seed technology. Plant Med. 2008;74:328.

66. Zych M, Furmanowa M, Krajewska-Patan A, Lowicka A, Dreger M, Mendlewska S. Micropropagation of Rhodiola kirilowii plants using encapsulated axillary buds and callus. Acta Biol Cracov Bot. 2005;47:83-7.

67. Schippmann U, Leaman DJ, Cunningham AB. Impact of cultivation and gathering of medicinal plants on biodiversity: global trends and issues. Inter-Department Working Group on biology diversity for food and agriculture. Rome: FAO; 2002.

68. Teklehaymanot T, Giday M. Ethnobotanical study of medicinal plants used by people in Zegie Peninsula, Northwestern Ethiopia. J Ethnobiol Ethnomed. 2007;3:12-23. 